\title{
Appropriating Public Private Partnership in Senior High School Program: A Socio-Cultural Approach to Policy Making
}

\author{
Peter G. Romerosa* \\ School of Education, Arellano University, Manila, Philippines
}

\begin{abstract}
The implementation of the Senior High School program in the Philippines illuminates the State's response to the changing landscape of the global market economy. Its salient features focus on the additional two year-senior high school program which highlights the development of middle level skills for national development and global competitiveness. In order to concretize the implementation of the program, the State entered into collaboration with the private schools which is commonly known as Public Private Partnership (PPP). In this collaboration, the government provides the guidelines and financing while the private educational institutions provide the academic service. Framed from a socio-cultural approach to policy making in education, this study aimed to unpack a particular implementation of PPP of a private institution in an urban area, examine the institutional policies that were created in response to PPP, and interrogate the impacts of these policies on micro social processes. Using interviews and focus group discussions for methodology, the researcher drew narratives and insights from on-the-ground actors. Further, the investigation looked into how authorized policy actors (school administrators) and nonauthorized policy actors (teachers, parents, and students) are appropriating policies within the operational framework of the PPP in the implementation of the senior high school program. The results demonstrated that multi-layered appropriation and exercise of the agency were explicitly and implicitly deployed in diverse social spaces by actors as a pragmatic and creative response to the new educational arrangement. The paper provides a lens to further develop understanding on how policy appropriation and production from the local context can inform institutional approaches in facilitating relevant student experience within the realm of PPP in education.
\end{abstract}

Keywords: Public Private Partnership, Socio-Cultural Approach, Policy, Education, the Philipines.

How to Cite (chicago-16th): Romerosa, Peter G. "Appropriating Public Private Partnership in Senior High School Program: A Socio-Cultural Approach to Policy Making." Udayana Journal of Law and Culture 2, no. 1 (2018): 52-72. https://doi.org/10.24843/UJLC.2018.v02.i01.p03.

DOI: https://doi.org/10.24843/UJLC.2018.v02.i01.p03

\section{Introduction}

\subsection{Background}

Consistent with Article 28 of the Convention of the Rights of the Child ${ }^{1}$ which asserts that States Parties recognize the right of the child to education, and with a view to achieving this right progressively and on the basis of equal opportunity, the

* E-mail/Corresponding Author: peterromerosa8888@gmail.com

1 The Philipines ratified this Convention in 1990. https://treaties.un.org/Pages/ViewDetails. aspx?src=IND\&mtdsg_no=IV-11\&chapter=4\&lang=en\#11 With the ratification, the Philipines was entrusted with the mission to "...undertake all appropriate legislative, administrative, and other measures for the implementation of the rights recognized in the Convention. See "The Philippines and the Convention on the Rights of the Child", http://bangkok.ohchr.org/news/crc.aspx. 
1987 Philippine Constitution mandates that the State shall establish and maintain a system of free public education in the elementary and high school levels. ${ }^{2}$ With the Enhanced Basic Education Act of 2013, the government expanded the basic education system from 10 years to 1 year of kindergarten, 6 years of elementary school, 4 years of junior high school, and 2 years of senior high school (hereinafter, SHS). ${ }^{3}$

In general, this bold educational reform is the government's approach to achieve inclusive growth by investing in human capital formation in order to reduce poverty and meet national development. Its salient feature focuses on the additional two-year senior high school program where a student selects a course track or specialization based on his or her ability, interest, and socio-economic capacity. A huge number of high school graduates do not pursue college education due to poverty. As a result, SHS was conceived to capacitate students with middle level skills (i.e., technical, vocational, and entrepreneurial skills) in preparation for employment.

Such paradigm shift in education entails subscribing to the twelve-year basic education global standard and also ensures that graduates of Philippine education will be globally competitive in terms of knowledge and skills. Fraught with the lack of teaching force and limited physical infrastructure to accommodate Grade 10 completers from the public school system, the state entered into a collaboration with private schools in providing academic service for the additional two-year senior high school program for public school grade 10 completers. Construed in multifarious meanings across scales (transnational, national, local), this study follows the notion of Public Private Partnership (hereinafter, PPP) as utilized by the World Bank and Organization for Economic Cooperation and Development (2008), which include (i) management and support services; (ii) operational services; (iii) infrastructure; the focus is primarily on those PPP's where the government guides policy and provides financing while the private sectors deliver the services to students. Similarly, PPP is an arrangement for the private sector to deliver infrastructure services for the public sector or to assist the public sector in its task of delivering infrastructure services to the public. ${ }^{4}$

This is articulated in the Department Order No.88 s 2010 of the Department of Education (hereinafter, DepEd) asserting that the State recognizes the complementary roles of public and private institutions in the educational system and shall

\footnotetext{
2 Article XIV Section 2 (2) of the 1987 Constitution of the Republic of the Philippines, http://www. officialgazette.gov.ph/constitutions / 1987-constitution/

3 Section 4 of the Republic Act No. 10533 An Act Enhancing the Philippine Basic Education System by Strengthening its Curriculum and Increasing the Number of Years for Basic Education, Appropriating Funds Therefor and for Other Purposes (Enhanced Basic Education Act of 2013), http://www.officialgazette.gov.ph/2013/05/15/republic-act-no-10533/

4 Jeffrey Delmon. Public Private Partnership Projects in Infrastructure: An Essential Guide to Policy Makers. (Cambridge: Cambridge University Press, 2011), 7.
} 
exercise reasonable supervision and regulation of all educational institutions. ${ }^{5}$ In practice, DepEd tapped private schools to provide the service for the senior high school program for Grade 10 completers from public schools through the Voucher Program. The Voucher Program is intended for Grade 10 (Junior High School) completers who wish to pursue Senior High School (SHS) education in non-DepEd Schools such as Private High Schools, Colleges, and Universities; Local Universities and Colleges (LUC); State Universities and Colleges (SUCs); and Technical and Vocational Schools, starting SY 2016-2017.

Hence, this global and state approach to education has direct and indirect impacts on diverse social spaces from the global landscape (i.e., relations between the State and education, the functions of educational institutions, and cultural reproduction) down to the micro-social processes (i.e., student participation, teacher's performance and disposition, leadership styles, parents' involvement, and the relationship among these actors). This paper unpacked these issues by looking into the contextual application PPP in a particular setting.

\subsection{Purpose of Research}

This investigation attempted to provide an analysis on how the technocratic approach to education policy initiatives has been undertaken in order to realize the rights to of Filipino children to free basic education. It also sought to interrogate how power relations among authorized policy actors (private school administrators, DepEd officials), and non authorized actors (teachers, parents, and students) are reconfigured.

Specifically, this research looked into: a) how actors are appropriating and implementing policies; b) how policy appropriation provides spaces for constructing, negotiating, and performing rights and identities. Further, this study aimed to enable us to see how local meaning-making and exercise of agency provide the basis for policy appropriation and production.

\subsection{Theoretical Framework}

Framed from a socio-cultural approach to policy making, ${ }^{6}$ this study views the policy in education as a practice of power and a language of power. ${ }^{7}$ This framework contends that policy actors are situated in diverse social realities. Diversity constitutes different interpretations and meanings that are mobilized in a social world in order to privilege or disenfranchise certain interests. Using appropriation as a lens of analysis,

5 Section 4(7) of the Department Education Order No. 88 s. 2010 Revised Manual of Regulations for Private Schools in Basic Education, https://www.scribd.com/document/349798176/DO-No-88-s-2010Revised-Manual-Private-Schools-pdf

6 Margaret Sutton and Bradley A. Levinson eds. Policy as Practice: Toward a Comparative Sociocultural Analysis of Educational Policy. Vol. 1. (London: Ablex Publishing, 2001), 23.

7 Cris Shore and Susan Wright (eds). Anthropology of Policy: Critical Perspective on Governance and Power. (London and New York: Routledge, 2015), 34. 
it recognizes on-the-ground actors as agentic individuals who play pivotal roles in the policy making process. In this a study, appropriation is construed as a form of creative interpretive practice engaged in by different actors in the policy making. Following this premise, when voices of non authorized actors are incorporated in policy making, they are in effect making new policy in situated locales and communities of practice (COP). In turn, the policy as a social-cultural practice looks beyond the text of the policy and how policy statements are articulated in day-to-day activities. In the practice of policy, actors produce, embed, extend, contextualize, and in some cases transform the text. In other instances, the marginalized actors, recontextualize, resist or subvert the ideological message of policy. ${ }^{8}$ Agency is exercised in order to respond to contextual constraints brought about new policies or innovations. ${ }^{9}$ Creative strategies are deployed in order to demonstrate mechanisms for survival. ${ }^{10}$ For Ball, Actors are making meaning, being influential, contesting, constructing responses, dealing with contradictions, attempting representations of policy. Policy is a discourse. ${ }^{11}$

For Foucault, policy is a complex and ongoing social practice of normative cultural production constituted by diverse actors across diverse contexts. Its immediate product is normative cultural discourse with positive and negative sanctions. Thus, policy (a) defines reality, (b) orders behavior, and (sometimes) (c) allocates resources accordingly. ${ }^{12}$

Policy as a normative cultural discourse presupposes a standard behavior in a model world, and structures such behavior through regulations. The normativity of policy entails the will to govern that seeks to meet or privilege certain agenda. On the other hand, it is also an intentional action that forms normative discourse. It is a process made by decisions from diverse social contexts.

Thus, appropriating policy, attends to how the local exercise of agency and dynamics of power relations affect policy making. Central in this position argues that policy actors occupy diverse positions of power, that is, their experiences, values, worldviews, and strategies greatly impact policy formation. In a socio-cultural sense, policy makers negotiate meanings based on their social contexts and such process is fundamental to social action. Negotiation is always part of policy making and

8 Deborah Reed-Danahay. Education and Identity in Rural France: The Politics of Schooling. (Great Britain: Cambridge University Press, 1996). 32-33.

9 Mustafa Emirbayer and Ann Mische, "What is Agency?" The American Journal of Sociology, 103, No. 4 (1998):962-1023.

10 Mark Priestley, Richard Edwards, Andrea Priestley, and Kate Miller. "Teacher Agency in Curriculum Making: Agents of Change and Spaces for Manoeuvre" Curriculum Inquiry 42, no. 2 (2012): $191-214$. https://doi.org/10.1111/j.1467-873X.2012.00588.x

11 Ball, Stephen. "What is Policy? Texts, Trajectories and Toolboxes". Discourse: Studies in the Cultural Politics of Education 13, no. 2 (2006): 10-17,DOI: http://dx.doi.org/10.1080/0159630930130203

12 Bradley A. U Levinson, Margaret Sutton, and Teresa Winstead. "Education Policy as a Practice of Power: Theoretical Tools, Ethnographic Methods, Democratic Options" Educational Policy 23, no. 6 (2009): 770, https:/ / doi.org/10.1177/0895904808320676. 
normative cultural production. ${ }^{13}$ In a nutshell, policy formation in the context of the practice of power sees education policy as a negotiated political process. Thus, education is a contested terrain. This means that education process and policies are historically situated, culturally bound and tied to the issues of power. In this context, policy making can be a powerful instrument for students to realize democratic participation in education.

\subsection{Methodology}

To examine the contextual application of PPP in a practical setting, this study involved a non-sectarian private school in Metro Manila as a service provider of the government for the implementation of the senior high school program. The site of the study was Lakandula School (pseudonym). The focus group discussions (hereinafter, FGD) ran from the third week of September until the second week of October 2017.

The researcher facilitated a series of FGD with students, teachers, and parents and conducted individual interviews with school administrators. Students and teachers represented different course tracks. As a method, FGD does not only mean obtaining accounts of individuals. Rather, it is a means to set up a negotiation of meanings through intra- and inter-personal conversations. ${ }^{14}$ Constructions of meanings presuppose that actors' lives are relational. Thus, their relationships influence their capacity to think and act.

The participants were purposively selected because they had hands-on insights to the research questions. In this study, two sets of students were chosen and interviewed in separate episodes. The first group was composed of students who academically excel in their strand, while the other group, comprised of students who struggle with their academics. The discussions among the participants provided the researcher with an opportunity to identify key issues and themes that emerged during the interaction.

\section{Result and Discussion}

\subsection{Legal and Policy Basis of Public Private Partnership in Education in the Philipines}

Over the past two decades, significant changes in the governance of education systems have been undertaken as international institutions, governments, firms, other organizations have promoted more hybrid partnership arrangements, involving new combinations of state and non-state actors engaged in a range of activities

13 Ian Cook and Mike Crang. Doing Ethnographies. Durham University (1995). 55 http://dro.dur. ac.uk/202/1/202.pdf?DDD14+dgg0arb+dgg0mac+dul0jk

14 Ibid. 779. 
within the education sector. These newer forms of education governance often operate across scales, through interactions between local, regional and national governments and organizations. ${ }^{15}$

These interactions have resulted in PPP in education. In the Philippine context, this model has been sought especially in the new educational reform in order to accommodate in the senior high school program. At the state level, this response is legitimized by the 1987 Philippine Constitution which asserts that State recognizes the complementary roles of the public and private institutions in the educational system. ${ }^{16}$

The type of PPP in the SHS program is similar the concept used by Organisation for Economic Co-operation and Development (OECD). This concept involves (a) management, maintenance, and support services; (b) operation services (such as pure management); and (c) infrastructure; where the government provides policy and financing while the private schools deliver the services to students. ${ }^{17}$ In this model, PPP is as an agreement between government and a private partner(s) (include the operators and financiers) according to which the private partner(s) deliver the service in such a way that the service delivery objectives of government are aligned with the profit objectives of the private partners(s) and where the effectiveness of alignment depends on a sufficient transfer of risk to the private partner(s). ${ }^{18}$

This form of implementation in the senior high school program has reconfigured Philippine educational landscape. Crucial aspects of the education reform reside in: a) collaboration between the government and private educational institutions in providing the academic service for the senior high school; and; b) partnership with business firms and stakeholders for on-the-job trainings of the students. ${ }^{19}$

In this new educational landscape, the private entity plays a crucial role in producing a public good. As a new key player in providing public education, Lakandula School has redefined its vision in order to adapt with the specifications of the educational reform. Explicit in the new vision statement of the private school is to train senior high school students to acquire functional knowledge and skills needed for them to respond to the needs of the local and global communities. This institutional articulation of education overtly expresses the relationship between education and the global economy. In this relationship, education as a state apparatus

15 Susan L. Robertson et, al. Public Private Partnership in Education. (UK: Edward Elgar Publishing Limited, 2012).1.

16 Article XIV, Section 4 of the 1987 Constitution of the Republic of the Philippines.

17 Susan L. Robertson et, al, Op.Cit, 6.

18 Organisation for Economic Co-operation and Development. Public-Private Partnerships: In Pursuit of Risk Sharing and Value for Money (Paris: OECD Publishing, 2008), 17.

19 Susan L. Robertson et, al, loc.cit. 
mimics the demands of globalization. ${ }^{20}$ This unidirectional relationship between the State and education is articulated in the Enhanced Basic Education Act of 2013 that determines "State shall give every student an opportunity to receive quality education that is globally competitive based on a pedagogically sound curriculum that is at par with international standards." ${ }^{21}$ As an approach to realize this objective of education, PPP has been institutionalized. At the micro level, such articulation has redefined the school's structural organization and operation including administrative roles and practices.

\subsection{School Articulation of the Public Private Partnership}

The principal shared:

"Since public high school students are the new potential market for the senior high school program, we are also trained to do marketing strategies. In practice, I go around several high schools to market our program and encourage students to enroll in our school. It easier to market big schools like ours, especially students would want to experience a new school environment with adequate facilities". ${ }^{22}$

At a local level, the articulation of PPP has (re)shaped administrative functions. School administrators perform entrepreneurial duties in line with the State's technocratic approach to mass education. As both instructional leader and marketing strategist, PPP has instituted new ways and patterns of carrying out duties and responsibilities in terms of relating to people.

The principal continued to lament that:

"Students have become more assertive of their right to education because PPP has given them the opportunity to access private education under the senior high school program. Moreover, it is more challenging to be a principal today because this new educational arrangement demands more workloads in terms of supervision and monitoring of teachers and students. It also extends the scope of my job to the public and government stakeholders. Adjustments take time because this is just the second year of implementation. There is limited knowledge about the senior high school implementation. To whom do we seek information about the program? I need to study in order to understand on-going issues." 23

20 Louis Althusser. On the Reproduction of Capitalism: Ideology and Ideological State Apparatuses, Translated by G.M. Goshgarian. (London: Verso Books, 2014), 94.

21 Section 2a of the Republic Act No. 10533 An Act Enhancing the Philippine Basic Education System by Strengthening its Curriculum and Increasing the Number of Years for Basic Education, Appropriating Funds Therefor and for Other Purposes.

22 Statement in FGD, ran from the third week of September until the second week of October, 2017 in a non-sectarian private school in Metro Manila. The site of the study was Lakandula School (pseudonym).

23 Ibid. 
The school administrator as marketing strategist has to generate productivity. However, their limited knowledge on running the program poses serious concerns and constraints among educational leaders. This is exacerbated by the dearth of contextual models for senior high school implementation. The major challenge dwells on how a leader navigates public and private domains and how to deal with the emerging legal and social issues brought about by the public-private collaboration. Within the realm of PPP in education, diverse dynamics of relationships have been formed, redefined, and regulated. Consequently,leadership style has been reconstructed in the context of productivity, accountability, and performativity. ${ }^{24}$ In the process, school leaders reconstruct their identities as they navigate their new duties and responsibilities.

\subsection{Appropriating Free Senior High School Program}

Table 1

Nonauthorized Policy Actors' Appropriation of the Free Senior High School Program. ${ }^{25}$

\begin{tabular}{|c|c|c|}
\hline Teachers & Parents & Students \\
\hline $\begin{array}{l}\text { "Like other paying students } \\
\text { in the junior high school and } \\
\text { college, you are also paid } \\
\text { through the voucher system. } \\
\text { So, take advantage of the } \\
\text { opportunity of being a private } \\
\text { school student under the } \\
\text { senior high school program." }\end{array}$ & $\begin{array}{l}\text { "This can be good and not } \\
\text { good." } \\
\text { "The voucher is free. However, } \\
\text { students' expenses for the } \\
\text { additional two years are } \\
\text { not." }\end{array}$ & $\begin{array}{l}\text { "It is our right to access } \\
\text { private education } \\
\text { under the senior high } \\
\text { school program." }\end{array}$ \\
\hline $\begin{array}{l}\text { "Enjoy the facilities; clean } \\
\text { environment and } \\
\text { air-conditioned classroom." }\end{array}$ & & \\
\hline
\end{tabular}

The implementation of the senior high school program is consistent with free basic education as articulated in Governance of Basic Education Act of 2001. ${ }^{26}$ It is hereby declared the policy of the State to protect and promote the right of all citizens to quality basic education and to make such education accessible to all by providing all Filipino children a free and compulsory education in the elementary

24 Stephen J. Ball, "Performativity, Commodification and Commitment: An I-Spy Guide to the Neoliberal University", British Journal of Educational Studies 60, no. 1 (2012). 19. https://doi.org/ 10.1080 /00071005.2011.650940.

25 Result of FGD, ran from the third week of September until the second week of October, 2017 in a non-sectarian private school in Metro Manila. The site of the study was Lakandula School (pseudonym).

26 Section 2 of the Act Instituting a Framework of Governance for Basic Education, Establishing Authority and Accountability, Renaming the Department of Education, Culture and Sports as the Department of Education, and for Other Purposes (Governance of Basic Education Act of 2001). 
level and free education in the high school level. In order to make free senior high school education accessible to the masses, PPP has been implemented. At the grassroots level, this educational landscape has generated diverse interpretations that influenced the dynamics of school participation among unauthorized policy actors (teacher, parents, and students) who are directly affected by the educational reform.

For teachers, they always emphasize in their narratives the advantage of free senior high school for public school students. A teacher said, "I always remind my SHS students that they have similar status with other regular paying students. Their tuition is paid by the State through the voucher program. This is to remind them that all students in this school are equal". ${ }^{27}$

The cultural deficit model assumes that poor attitudes towards schooling and under achievement are profoundly shaped by economic status and familial origin. In this model, public school students are perceived as lazy and show lack of interest in schooling. Reminding students of the opportunity to avail of the free senior high school program in a private school is a strategy for a teacher to call students' attention so that they will focus on their studies and strive harder.

On the other hand, students' interpretation of free education is an assertion of their right to education. They are aware that basic education is provided for by the State for free and they have a strong voice in choosing a school where they can continue their senior high school. This practice corroborates with the principal's narratives.

She said, "When we market, we make it a point that we are able to persuade and attract students because they are the ones who will enroll in the programs. They can decide and choose where to enroll for their SHS"28

However, the most critical among the non authorized policy actors are the parents. Although the senior high school is free, the additional two years imply an extension of their financial support to their children's education. For them, the additional expenses such as daily school allowances, transportation fare, school uniform, and school projects are more expensive than the cost of the voucher.

PPP is the meeting point between the structure and local actors. The interpretations reflect different actors' social contexts and are informed by levels of entitlement and impacts of the program. The most affected stakeholders demonstrate the most critical attitude towards the reform.

27 Statement in FGD, Op.Cit.

28 Ibid. 


\subsection{The Voucher as a Mechanism of Control}

Table 2

Participants' Interpretation and Negotiation with the Voucher Program ${ }^{29}$

\begin{tabular}{|l|l|l|l|}
\hline \multicolumn{1}{|c|}{ Administrator } & \multicolumn{1}{|c|}{ Teachers } & \multicolumn{1}{c|}{ Parents } & \multicolumn{1}{c|}{ Students } \\
\hline $\begin{array}{l}\text { were attracted to big } \\
\text { schools. At the same }\end{array}$ & $\begin{array}{l}\text { hard and fell them to study } \\
\text { senior high school, } \\
\text { time, we offer no } \\
\text { because if they fail, } \\
\text { top-up voucher } \\
\text { policy." }\end{array}$ & $\begin{array}{l}\text { their parents will pay } \\
\text { their tuition fees." } \\
\text { school expenses." }\end{array}$ & $\begin{array}{l}\text { "We will transfer } \\
\text { to a state univer- } \\
\text { sity for college } \\
\text { because we can- } \\
\text { not afford to pay } \\
\text { the tuition in a } \\
\text { private tertiary } \\
\text { school." }\end{array}$ \\
& $\begin{array}{l}\text { because they are } \\
\text { aware that they are } \\
\text { paid through the } \\
\text { voucher system. } \\
\text { We are compelled to } \\
\text { promote students } \\
\text { even they do not } \\
\text { deserve to pass." }\end{array}$ & & \\
& &
\end{tabular}

The voucher is a subsidy given by the State to qualified Grade 10 completers to enable them to enroll in a non-DedEd Senior High School of their choice. ${ }^{30}$ The assistance is meant to defray the cost of the total school fees charged by a non-DepEd SHS. The entitlement is not given to the students in cash; DepED instead pays directly to the non-DepEd SHS where the student enrolls. Voucher recipients from public/DepEd JHS who will enroll in a non-DepEd SHS located in the National Capital Region (NCR) receive a full voucher amount of PhP 22,500 or US\$ 439.754. As a strategy, Lakandula offers no-top-up voucher policy. This means that no additional fees are collected on top of the standard amount of the voucher. This policy appealed to students whose parents have very limited capacity to pay additional fees. As a result, many students from low-income families took advantage of the notop-up policy as a primary reason for enrolling in Lakandula School. Secondary to this is the desire of public school students to study in a new school environment, and lastly, is the experience to be a student in a big school. Being able to meet these three main reasons, Lakandula School was able to attract a huge number of students from disenfranchised families. In practice, the capacity for students to finish the program does not only depend on the school's vision, but also on how students will relate to their teachers and the family support of the program.

29 Result of FGD, Op.Cit

30 Voucher Program. http://www.deped.gov.ph/k-to-12/faq/voucher-program 
The voucher has regulated school participation and involvement of students, parents and teachers. Explicitly and implicitly, the voucher system promotes mass education on the one hand, and encourages mass promotion on the other. Teachers are challenged to create proactive approaches in order to sustain students' school participation. However, they are constrained to promote even those students who demonstrated tardiness and failed to meet school requirements. One mechanism to address this issue is to persuade parents to take an active involvement in the education of their children.

In order to secure parents' compliance with the program, parents were informed of regulation that: a student loses the voucher or subsidy if he or she fails to complete the program. In this case, parents are required to shoulder the expenses should their children wish to continue SHS in any non-DepEd schools. This condition has compelled parents, especially from the poor sector to actively participate in students' completion of the SHS program. Although parents are critical about the program, at the end, they still subscribe to the policy in order to avoid losing the subsidy. More than anyone else, the student and their families are the most affected when former fails to complete the program.

The voucher program has provided spaces for students to exercise their agency. It has given them entitlements in terms of choosing a school and the right to avail of private education for SHS. Students are assertive, competitive and eager to try new things. As the assistant principal noted:

They do not seem to carry a marginalized status. When teased, they fight back.

Students are aware of their temporal social status in the program. Such status is interwoven with opportunities and constraints. For bright students, studying in a private school is an opportunity for them to learn and get good grades. One student from a cream section stated: "I think all of us in class seem to be competitive because we have to maintain excellent grades. We are doing this for practical reasons; for our families and future". ${ }^{31}$

The motivation for bright students to earn excellent academic standing in SHS is a stepping stone for them to enter into state universities. They will not choose to stay at Lakandula School because their families cannot afford private tertiary education. On the last year in the program, the average number of sleep hours for students in a cream section is five hours a day. This is due to heavy requirements for the specialized courses. They are required to have a full grasp of contextualized and specialized courses in preparation for employment or tertiary education. The culture of competition and the voluminous demands of the program make SHS a challenging experience, especially for bright students.

31 Statement in FGD, Op.Cit 
In contrast, students in a regular class, have an average number of eight sleep hours a day. They exert effort in their studies within the limits of their capacity. They still have time to do other activities such playing basketball, meeting friends, doing household chores after school hours. One student from the regular class articulated:

"Our class is divided into two: Students who belong to Team GC (Grade Conscious) and those who belong to Team Mobile. Students in the GC category are so determined to earn good grades. Their lives are limited to academics. I belong to Team Mobile. I exert effort according to my ability. I know when to be serious in my studies." ${ }^{32}$

Majority of students from cream and regular sections, express a desire to pursue a college education. For struggling students especially those coming from poor families, SHS is not about getting good grades. Their motivation is to earn the SHS degree as their ticket to employment in order to help their families. If the voucher is extended to college, they would rather stay in Lakandula School.

Participants negotiate and accommodate the direct and indirect ideological messages of the voucher program. Accommodation operates within the following dynamics of social processes: a) teachers' deployment of pragmatic strategies to sustain students' school participation; b) parents' involvement; and c) students' positive interest to finish SHS. On the other hand, negotiation takes place as each actor interprets and recontextualizes the program to fit their interests.

\subsection{Views about Senior High School}

The table below presents different views of actors about the senior high school program. These views represent actors' social position, participation, meaning-making about education and the impacts of the senior high school program on the particular lives of actors.

32 Statement in FGD, Op.Cit 
Table 3

Views of Actors about the Senior High School Program ${ }^{33}$

\begin{tabular}{|c|c|c|c|}
\hline Administrator & Teachers & Parents & Students \\
\hline $\begin{array}{l}\text { "SHS bridges the } \\
\text { transition from HS to } \\
\text { College." }\end{array}$ & $\begin{array}{l}\text { "SHS is a preparation } \\
\text { for College." } \\
\text { "Subjects that we } \\
\text { teach are not within } \\
\text { the field of our } \\
\text { expertise. We are } \\
\text { trained to teach the } \\
\text { JHS, not the SHS." } \\
\text { "We are limited by } \\
\text { the lesson plan." }\end{array}$ & $\begin{array}{l}\text { "They are still in } \\
\text { high school } \\
\text { students; I will } \\
\text { send them off to } \\
\text { college. Who will } \\
\text { hire them if they } \\
\text { are only SHS } \\
\text { graduates?" } \\
\text { "We are not } \\
\text { confident if } \\
\text { teachers can } \\
\text { deliver. Most of } \\
\text { them are fresh } \\
\text { graduates." }\end{array}$ & $\begin{array}{l}\text { "We are being } \\
\text { prepared for } \\
\text { college." } \\
\text { "We feel that we } \\
\text { are under an } \\
\text { experiment." } \\
\text { "Our subjects } \\
\text { are difficult." } \\
\text { "We expect to } \\
\text { have experi- } \\
\text { enced and ex- } \\
\text { pert } \\
\text { teachers to teach } \\
\text { us since we are } \\
\text { in SHS already." }\end{array}$ \\
\hline
\end{tabular}

In general, similar perspective rests on the notion that the program prepares students for a college education, except for a few who would like to work because their families are not financially capable to support their tertiary education. Parents' skepticism shows lack of confidence for their children to land a decent job if they are not college graduates. Given enough resources, they will send them off their children to college. The dominant view on completing a college degree is an integral part of Filipino society. This practice reflects the value of Filipino families on education. In Filipino society, any individual who has completed a college degree gives honor to his or her family and the community. It is also socially perceived that one's occupation is determined by a person's educational attainment. Hence, the option to work over pursuing a college degree after SHS is less socially accepted but a practical choice for economically disadvantaged students. Choosing or not choosing to continue tertiary education is a collective decision that is always mediated by the family's forms of capital (economic, cultural, social and emotional).

SHS implementation has opened teaching opportunities for education and non-education graduates. On the other hand, it has also created constraints because majority of the teachers are fresh graduates who have limited knowledge and social skills in relating to SHS students. Some non-education graduates were field practitioners who ventured into teaching for a career change. They have content expertise but they lack pedagogical and methodological skills. 
Subjects in the old tertiary curriculum were incorporated in the SHS program. In terms of learning the academic content areas, students feel like college students. In this regard, they expect that teachers should exhibit expertise in the subjects they teach. Students in the cream section are more critical in identifying teachers who have the capacity to deliver effective instruction. Students are aware of the emerging issues of the program. At the center of these on-the-ground issues, students feel that they are under a big experiment. Student agency is essential in this situation. One student uttered:

"We believe that we are all adjusting. Teachers are adjusting because most of them are fresh graduates. From our end, we have to do the same. Our teachers easily get hurt when we challenge them. We leverage our relationship in order to develop a good rapport with our teachers. Because we have a cordial relationship with them, they are open to negotiation. We can ask them to extend the deadline for submission of requirements or lessen the volume of our school projects especially when they are getting heavier." 34

Diverse views on education illuminate contradictions between policy statements and cultural practice. Mass education in the context of SHS implementation is provided for free so that majority of the socially disadvantaged SHS graduates can join the labor force. On the other hand, academic people interpret the subliminal text of SHS program as a preparation for college life. Such interpretation is consistent with the normative social practice of completing a college degree. Socio-economic issue and student academic ability are two dominant factors that shape a family's decision for their children's education.

In responding to problematic situations, teachers and students have developed creative and pragmatic strategies. Teachers organized social networks in order to draw emotional support from each other and share resources. These networks became a venue for cooperation and capacitated teachers to collectively negotiate their concerns with the system. On the other hand, students used time management as a strategy to address constraints due to heavy requirements. On a collective level, they managed to establish a harmonious relationship with their teachers so that they can bargain with their concerns. 


\subsection{Contemporising the Reasonable Person}

The table below presents different views of actors about the identity formation.

Table 4

Views of Actors about the Identity Formation ${ }^{35}$

\begin{tabular}{|c|c|c|c|}
\hline Administrator & Teachers & Parents & Students \\
\hline $\begin{array}{l}\text { "Categorically speak- } \\
\text { ing, SHS students } \\
\text { are minors." } \\
\text { "Treat them as } \\
\text { college students, but } \\
\text { in legal documents } \\
\text { treat them as HS." }\end{array}$ & $\begin{array}{l}\text { Older teacher: } \\
\text { "I treat them like my } \\
\text { son and daughter." } \\
\text { Young teacher: } \\
\text { "I am afraid to my age; } \\
\text { If they learn reveal } \\
\text { my age; If they learn } \\
\text { about it; they may not } \\
\text { respect me anymore." } \\
\text { "It is hard to earn } \\
\text { students' trust if the } \\
\text { teacher and his or } \\
\text { her students belong } \\
\text { to the same age } \\
\text { bracket." }\end{array}$ & $\begin{array}{l}\text { "Students are not } \\
\text { allowed to have } \\
\text { a sleepover at } \\
\text { their classmates" } \\
\text { house." } \\
\text { "They are only HS } \\
\text { students." } \\
\text { "We are disoriented. } \\
\text { Their subjects are } \\
\text { like those in } \\
\text { college but they } \\
\text { are in HS." }\end{array}$ & $\begin{array}{l}\text { "They are many } \\
\text { restrictions. } \\
\text { They want us to } \\
\text { behave like } \\
\text { college students } \\
\text { but they treat us } \\
\text { like HS } \\
\text { students." } \\
\text { "How to behave } \\
\text { like a mature } \\
\text { student? To } \\
\text { whom should } \\
\text { we ask? Where } \\
\text { do we go, to the } \\
\text { high school } \\
\text { library or college } \\
\text { library?" }\end{array}$ \\
\hline
\end{tabular}

The entrance of the first batch of grade 10 completers had been delayed due to the SHS implementation. Consequently, the program has created a new social status; a transition stage between junior high school and college. The crucial issue in this transitional stage is identity formation. Students ask: What does it mean to be an SHS student? Construction of SHS identity is determined by how the policy describes them, how the larger society relates to them, and how SHS students themselves make sense of their social interactions. Academic actors display new patterns of relating with students.

The principal explained:

"When it comes to legal documents they are treated as high school. This means that students should always secure parents' consent through a waiver before allowing them to engage in curricular or extra-curricular activities. For example, if it is dismissal time, they have to go home immediately, if they have to stay to do other activities like rehearsing for a school play or complete a project, they need to secure a waiver from their parents. However, without the SHS, they are 
supposed to be in college already- meaning, there are some activities that do not require them to submit a waiver. So, in terms of interpersonal relations, I instructed my teachers to treat them like college students." ${ }^{36}$

For the young teachers especially the fresh graduates, they struggle to earn students' trust. Students see young teachers as barkada, cohorts, friends, brothers or sisters because they belong to the same age bracket. For this reason, some teachers do not tell their students about their real age. They would only tell about it when they have already secured the trust of their students.

Inevitably, relationships within the mainstream society are hierarchical. Students look up to teachers who can share with them relevant knowledge, and meaningful insights from their experience. A student said, "We appreciate a teacher who imparts with us insights about the issues that we are facing." 37

In practice, the majority of the teachers in the senior high school fall within the same developmental stage as their students. As a result, teachers and students may one way or another; undergo the same developmental issues and challenges. What kind of experience would teachers bring into their class in order to guide their students who in a very crucial stage? Within the limitations of the program, who should adjust, and who is the most affected?

Epistemologically, teaching is an emotional labor. It is given by someone who has the content expertise and broad experience who plays a significant role in the character formation of a student. Teaching is establishing a teacher-student relationship. Such relationship is built on trust and earned through the quality of emotional and intellectual experience brought into the social ties. These new dynamics of relationship affect students' construction of their identity.

\section{Another student said:}

"As a high school student, we wear school uniform similar to that of the JHS. We do the same co-curricular and extra-curricular activities like those in the JHS curriculum. We are asked to fall in line along the corridor like children in grade school. However, like college students, we also have practicum, our subjects are specialized and contextualized and the school year is divided into two semesters. In terms of the way we should behave, adults tell us to act like a college student." 38

Because students carry a SHS social status, the social perception towards SHS has been created. SHS has created a dual identity that poses confusion not only for students but also for other community people. A mother said, "My son is still in high
36 Ibid.
37 Ibid.
38 Ibid. 
school so I will not allow him to have a sleepover at his friends' house. He has to observe strict regulations because he is still minor. However, I am quite disoriented about his subjects. They are difficult." 39

This socially constructed status predisposed students to enter into the liminal stage. A liminal space is a transitional stage where a student's identity is reconstructed and transformed in order to be reincorporated into the society. ${ }^{40}$ In the learning process, there is an epistemological reformulation of a student's meaningmaking as he or she is exposed to learning rituals and experiences in preparation for the ontological shift. This 'betwixt and between space' is a vulnerable experience but also as loaded with opportunities for transformation and empowerment. Drawing on students' perspectives and narratives, confusions reside on different interpretations of what it means to bean SHS student, including the contradictions between what is in policy and what is happening on the ground. The explicit agenda of the SHS program is to reincorporate students into the neoliberal world, whether they participate in the labor force or pursue higher education. In this liminal space, the learning of the middle-level skills is integral in the social integration. On the other hand, the cultural status of an SHS student predisposes the wider society to subject students to strict regulations. Students have to negotiate with their new identity and emerging issues and opportunities in the liminal space. SHS liminal space is a social site of contestation and identity formation not only for students but also their parents and teachers.

\section{Conclusion and Recommendation}

Education cannot be analyzed independently of the wider social system. As such, the implementation of public private partnership (PPP) in education in the Philippines elucidates the state's response to global demands. In practice, Enhanced Basic Education Act of 2013 was enacted, creating additional two years in the senior high school. The implementation of this education reform constituted a PPP model that shares similarities with the one utilized by the OECD, which defines PPP as a contract between the government and a private, where the government guides the policy and the private institution delivers the service.

Education is a social apparatus of the State that reproduces the neoliberal agenda of the global economy. To meet this agenda, the State implemented the senior high program using the PPP in order to broaden school participation of masses. In this collaboration, the private institution provides the academic service while the government provides the guidelines and financing. In this new educational arrangement, education as a public good is served by a private institution. The technocratic approach in providing public education has redefined public-private collaboration,

\footnotetext{
39 Statement in FGD, Op.Cit

40 Victor Turner. The Ritual Process: Structure and Anti-Structure. (Chicago: Aldine, 1969), 94.
} 
especially non authorized actors' participation in education. At the macro level, the partnership elucidates strong identification between the school and the State in line with the national development and global competitiveness, but much of what occurred at the local level reflects a strong appropriation of policy. Neoliberal agenda of education is interpreted in ways that local identity, familial values, and cultural meanings are negotiated in order to serve personal or familial interests. However, local strategies are deployed as a practical response to the disabling impacts of the policy. In this process, the agency is exerted while identity is negotiated, reconstructed, and performed. Generally, the response seems to show the reproduction of the instrumental view of education. Educational leaders are trained to dispense the instrumental value of education for taking a new role as a marketing strategist. Nevertheless, the exercise of agency serves to legitimize and reproduce the instrumental assumption of education.

Moreover, emerging issues brought about PPP in education in general, and the implementation of SHS, in particular, are happening in a liminal space. One crucial issue in this liminal stage is identity formation. Students are treated as a high school on the one hand and college on the other. As a result, students are confused as to how to behave with a dual identity. In negotiating with their dual identity and the expectations of the State, they deploy personal strategies consistent with their goals and aspirations in life. Embedded within these goals is the desire for socio-economic mobility in order help their families escape from poverty. In policy appropriation and production, it is crucial to pay attention to the social and individual exercise of agency, cultural meanings, history, power relations, and identity construction at the local context.

The paper provides a lens drawn from a socio-cultural approach to policy making to further develop an understanding on how policy appropriation and production from the local context can inform institutional approaches in facilitating relevant student experience within the realm of PPP in education. 


\section{BIBLIOGRAPHY}

\section{Book}

Althusser, Louis. On the Reproduction of Capitalism: Ideology and Ideological State Apparatuses. Translated by G.M. Goshgarian. London: Verso Books, 2014.

Reed-Danahay, Deborah. Education and Identity in Rural France. The Politics of Schooling. Great Britain: Cambridge University Press, 1996.

Delmon, Jeffrey. Public Private Partnership Projects in Infrastructure: An Essential Guide to Policy Makers. Cambridge University Press, 2011.

Organisation for Economic Co-operation and Development. Public-Private Partnerships: In Pursuit of Risk Sharing and Value for Money. Paris: OECD Publishing: 2008.

Robertson, S. L et, al. Public Private Partnership in Education. Edward Elgar Publishing Limited, UK, 2012.

Sutton, Margaret, and Bradley A. Levinson, eds. Policy as Practice: Toward a Comparative Sociocultural Analysis of Educational Policy. Vol. 1. London: Ablex Publishing, 2001.

Shore, C. \& Wright, S (eds). Anthropology of Policy: Critical Perspective on Governance and Power. London and New York: Routledge, 2005.

Turner, Victor. The Ritual Process: Structure and Anti-Structure. Chicago: Aldine, 1969.

\section{Journal Article}

Ball, Stephen J. "Performativity, Commodification and Commitment: An I-spy Guide to the Neoliberal University." British Journal of Educational Studies 60, no. 1 (2012): 17-28. https://doi.org/10.1080/00071005.2011.650940

Ball, Stephen J. "What is Policy? Texts, Trajectories and Toolboxes". Discourse: Studies in the Cultural Politics of Education 13, no. 2 (1993): 10-17. http:// dx.doi.org/ 10.1080/0159630930130203

Emirbayer, Mustafa, and Ann Mische. "What is Agency?." American Journal of Sociology 103, no. 4 (1998): 962-1023. 
Levinson, Bradley AU, Margaret Sutton, and Teresa Winstead. "Education Policy as a Practice of Power: Theoretical Tools, Ethnographic Methods, Democratic Options." Educational Policy 23, no. 6 (2009): 767-795. https:// doi.org/10.1177/0895904808320676

Macris, Vicki. "The Ideological Conditions of Social Reproduction." Journal for Critical Education Policy Studies 9, no. 1 (2011): 20-46.

Priestley, Mark, Richard Edwards, Andrea Priestley, and Kate Miller. "Teacher Agency in Curriculum Making: Agents of Change and Spaces for Manoeuvre." Curriculum Inquiry 42, no. 2 (2012): 191-214. https://doi.org/10.1111/ j.1467-873X.2012.00588.x

\section{Legal Document}

The 1987 Constitution of the Republic of the Philippines

Republic Act No. 10533 An Act Enhancing the Philippine Basic Education System by Strengthening its Curriculum and Increasing the Number of Years for Basic Education, Appropriating Funds Therefor and for Other Purposes

An Act Instituting a Framework of Governance for Basic Education, Establishing Authority and Accountability, Renaming the Department of Education, Culture and Sports as the Department of Education, and for Other Purposes (Governance of Basic Education Act of 2001)

Department Education Order No. 88 s. 2010 Revised Manual of Regulations for Private Schools in Basic Education

Universal Declaration on Human Rights

Convention on the Rights of the Child

\section{Website Content}

Cook \& Crang (1995). Doing ethnographies. Durheim University. http://dro.dur. ac.uk/202/1/202.pdf?DDD14+dgg0arb+dgg0mac+dul0jk

K - 12 Program. http:/ /www.gov.ph/k-12/\#about.

Organisation for Economic Co-operation and Development (2012) Recommendation of the Council on Principles for Public Governance of Public-Private Partnerships. Retrieved on November 20, 2017 from: https://www.oecd.org/governance/ budgeting/PPP-Recommendation.pdf 
Legal and Policy Basis of PPP in Education in the Philipines.https://www.teacherph.com/legal-bases-of-philippine-educational-system/

Voucher Program. http:/ /www.deped.gov.ph/k-to-12/faq/voucher-program

United Nations. Universal Declaration of Human Rights, 1948 Adopted by the United Nations General Assembly on 10 December 1948 at the Palais de Chaillot in Paris, France. http://www.un.org/en/universal-declaration-human- rights/

United Nations, Treaty Collection, https://treaties.un.org/Pages/ViewDetails. aspx?src=IND\&mtdsg_no=IV-11\&chapter=4\&lang=en\# 11

Office of the High Commissioner for Human Rights, Regional Office for South-East Asia, http://bangkok.ohchr.org/news/crc.aspx 